\title{
Institutions Matter in Transition, But So Do Policies
}

\section{OLEH HAVRYLYSHYN ${ }^{1} \&$ RON VAN ROODEN ${ }^{1}$}

International Monetary Fund. E-mail: rvanrooden@imf.org

Received 2 August 2002; revised 20 September 2002; accepted 23 September 2002

\begin{abstract}
This paper analyses the importance of developing market-enhancing institutions for restoring economic growth in transition economies during 1991-98. The paper's main finding is that the development of an institutional framework has indeed a significant positive impact on growth, but that progress in achieving macroeconomic stabilisation and implementing broad-based economic reforms remain the key determinants of growth in transition economies.

Comparative Economic Studies (2003) 45, 2-24. doi:10.1057/palgrave.ces.8100005
\end{abstract}

Keywords: growth, institutions, transition countries, public policy

JEL Classifications: P2, P21, P47, O21

'When I was growing up in Peru, I was told that the farms I visited belonged to farming communities and not to the individual farmers. Yet as I walked from field to field, a different dog would bark. The dogs were ignorant of the prevailing law; all they knew was which land their masters controlled. In the next 150 years those nations whose laws recognize what the dogs already know will be the ones who enjoy the benefits of a modern market economy.' (Hernando de Soto)

\section{INTRODUCTION: RECENT ANALYSIS ON GROWTH IN TRANSITION}

At the First Dubrovnik Conference on Transition in 1995, de Melo et al. (1997a) presented a paper analysing patterns of transition, including growth,

\footnotetext{
${ }^{1}$ The authors are staff members of the International Monetary Fund. The views expressed are those of the authors and do not necessarily represent the position or official views of the International Monetary Fund. We are grateful for the comments of John Odling-Smee, Mario Blejer, participants at the Fifth Dubrovnik Conference on Transition Economies, and two referees of this journal.
} 
to that date. Their econometric analysis of growth provided a clear new direction for subsequent efforts to explain recovery and growth in transition, by showing that while inflation stabilisation was a necessary condition, as emphasised by Fischer et al. (1996), an equally important condition was progress on economic liberalisation. In later work, de Melo et al. (1997b) added a detailed analysis of the role of initial conditions. Broadly similar results are obtained in Fischer et al. (1996). The now much larger literature on recovery in transition ${ }^{2}$ tries to explain growth differences in terms of three main categories of explanatory factors: (i) macroeconomic variables, such as the level of inflation and the size of the budget deficit; (ii) variables describing progress made with structural reforms, in particular liberalisation and privatisation; and (iii) variables characterising initial conditions, such as the degree of macroeconomic and structural distortions at the beginning of transition, or wars and internal conflict.

Subsequent studies such as those of Wolf (1997), Havrylyshyn et al. (1998), and Berg et al. (1999) have combined these three categories and extended the period of study to determine their relative importance in explaining both the U-shaped time profile of output as well as the crosscountry differences in growth performance. These more recent studies broadly confirm earlier conclusions about the need for stabilisation and the crucial importance of economic liberalisation, and also reach new conclusions on the importance of initial conditions and on time-lag effects. Thus, while de Melo et al. showed a strong effect of initial conditions, both Berg et al. and Havrylyshyn et al. conclude that the effect has declined over time. The latter further demonstrate that any negative effect of initial conditions (such as a high degree of industrialisation) can be easily compensated by slightly more progress on reforms. ${ }^{3}$ These later studies also show that negative effects on output of early and rapid liberalisation are more than compensated by lagged positive effects. ${ }^{4}$

However, this growing body of econometric analysis has not yet gone very far to include a fourth category of factors, which are increasingly cited in

${ }^{2}$ This literature is reviewed in Havrylyshyn et al. (1999).

${ }^{3}$ The magnitude of this trade-off is illustrated in Havrylyshyn et al. (1998). Adverse initial conditions reduce growth by a substantial amount compared to the sample of 25 countries: -1.4 percentage points for Ukraine and -0.8 percentage points for Russia. This disadvantage is, however, easily offset by a little more structural reform; RI would need to rise from 0.50 to 0.64 in Ukraine, or from 0.70 to 0.74 in Russia.

${ }^{4}$ Berg et al. capture this through a long lag structures specification; Havrylyshyn et al. show, in addition, that by separating the period into that of 'destruction' (1990-1993) and 'creation' (1994 onwards), one sees more clearly the long-term strongly positive effects of liberalisation on growth, and that for the creation or growth period the role of initial conditions, while still statistically significant, is much diminished in explanatory power. 
4

other writings on transition - and growth in general - namely development of institutions that enhance the market environment. There is, on the one hand, a large literature on the importance of institutions, and there exists, on the other hand, a large number of synthetic indicators of the business-friendly environment: political or business risk; degree of corruption, effectiveness of governance; economic freedom; effectiveness of legal system and protection of property rights; political freedom, etc. The main objectives of our paper are to compile available institutional indicators for transition economies, and carry out a first simple econometric test of how much explanatory value is added by such institutional indicators in regressions of growth in transition economies. We do not pretend here to build a comprehensive theory of transition or even a theory of growth in transition that incorporates institutional development. Our aim is simpler; given the growing consensus that market-friendly institutions do matter, and that many cardinal measures of the degree of development of such institutions exist, we ask: is the statistical analysis of growth improved by including these variables?

It is worth noting some important differences between the above transition studies and the standard growth equation specification à la Barrow and Sala-I-Martin. The classic specification includes something like initial income levels to capture convergence effects, and proxies for factor inputs and technology. Virtually all specifications for transition countries differ from this because they consider not a long-run equilibrium path of growth, but a short- to medium-term adjustment of the economy from a high degree of central plan period inefficiency, as well as recovery from the initial output decline. In this framework, as outlined in Havrylyshyn (2001), initial condition variables (including inter alia per capita income) should not be considered as capturing long-run convergence; rather, more typically, they are intended to reflect the negative burden of overindustrialisation. Factor inputs are thought by most authors to matter little as the early recovery is largely based on efficiency benefits of resource reallocation, improved incentives, and corrected price signals. Indeed, investment variables when tried, give negative and/or insignificant results. The same logic suggests non-relevance of any trend technology variables. Of course, in the microsense, there may be a number of small technological and capital stock changes (plus employment expansion) for firms/sectors that are new growth points. However, the large disinvestments in the inefficient soviet-period capital stock overwhelm this; hence, aggregate growth is not positively related to aggregate factor input changes.

The next section of the paper reviews selectively the use of such indicators in growth regressions for nontransition countries. Then, we describe and assess 10 data series of institutional development that we 
collected, which cover a large number of transition countries. Consequently, we present the results of econometric analysis of growth in 25 transition countries in the period 1991-98, adding to a conventional formulation the different institutional variables described here. Finally, we summarise our findings and suggest further directions for research.

\section{INSTITUTIONAL CONDITIONS AS DETERMINANTS OF GROWTH}

It has become commonplace, if not almost universal, to worry about the institutional framework of the rule of law and property rights protection as a 'missing ingredient' to ensure economic growth and prosperity (see De Soto, 1998). The locus classicus describing the way in which institutional development contributes to effective markets is the work of North (1990, 1993), while Murrell (1992, 1996) discusses the problem of sequencing liberalisation and institutional development in the process of transition. In this section, we review briefly the studies that have incorporated institutional variables in econometric analysis of growth.

\section{Early empirical work in the new growth theory}

In their pioneering empirical work of new growth theory, Barro and Sala-IMartin (1994) include with good statistical results a variable measuring political instability. Their results show that an increase of political instability by one standard deviation from the mean in a sample of 97 countries lowers the growth by a substantial amount, 0.4 percentage points per year. Political instability is also the metric used by Easterly and Levine (1998) for African countries, and they find a statistically significant impact on growth. So too do Calamitsis et al. (1999), who use, however, a broader institutional measure, political freedom in addition to a dummy for war (which may capture the political stability effects). Easterly and Levine go further, however, showing that the main source of political instability in this sample of countries is the degree of ethnic fragmentation. They also expand into other institutional areas, at least tentatively, by demonstrating that high ethnic fragmentation explains not just political instability, but also other direct determinants of growth, such as low schooling and poor infrastructure. That the latter are a reflection of poor governance (ie low institutional development) is strongly affirmed by many studies that use some metric of the degree of corruption to explain ineffective government. Thus, Tanzi and Davoodi (1997) show how corruption results in low expenditures on health and education (where bribery opportunities are limited), and large but poorly executed public investment projects (where bribery opportunities are legion). An excellent 
summary of how well corruption indices explain statistically various performance measures, such as growth or investment ratios, is found in the work of Mauro (1997) and Wei (1998). While corruption indices are not a direct measure of institutional development, they are surely an excellent overall proxy; hence, these results are strongly supportive of the broader hypothesis that institutional development matters.

\section{Categories of institutional factors}

Political instability is surely too narrow a definition of institutional development, and corruption too all-encompassing and more of a result of institutional conditions than a measure of those conditions. While it is good to keep the concept of institutions relatively simple, it may be useful to elaborate it slightly. We propose two distinct categories of market-friendly institutions that are separately measurable in principle, and with possibly separate effects on performance:

- legal framework for economic activity (which may include establishing legislation for free economic activity, bankruptcy, contract law - and most important enforcing such legislation even-handedly and transparently; the last is what 'rule of law' and 'security of property rights' really mean);

- $\quad$ political and civic freedom (which includes democratic process, freedom of assembly and speech, equal treatment by political and judicial bodies, etc.).

Economic liberalisation (which may include elimination of price distortions, opening markets to competition, deregulation, unifying exchange regimes, privatisation, and allowing private activity) could be regarded as a third distinct category of market institutions. However, we think that structural reforms such as price and trade and exchange liberalisation as well as privatisation are of a different nature than the development of market-enhancing institutions. The former captures mostly measures that can be introduced within a short time frame. Institutional reforms on the other hand, by their very nature, take much longer to develop. Therefore, we treat structural reforms in our analysis as elements of what we call policies, or better still 'good policies', in order to be able to distinguish their effect on economic performance from the impact of institutions per se, which we treat here more as a variable representing 'conditions' (although we do recognise that institutions ultimately stem from policies).

Some of the indicators that we describe in the next section (and then use in the section that follows) fall neatly into one of the three subcategories above, but many are in effect proxies or a measure of the overall climate 
resulting from good institutions. Such indices consist of averaging the above three into an overall index of 'freedom', or 'risk', or 'transparency', or 'corruption'. While several of these proxies work well in statistical analysis as this section describes below - there is an argument for trying to use a metric that comes closer to the above three concepts of institutional development. First, a direct measure of the degree of institutional development is surely better to have than a 'result' measure such as corruption or risk. Secondly, and consistent with the institutional approach, the effect on performance of these three is not a simple one, but involves a rather more complex model where the pace of development of each could be different, where the three interact in both a substitution and complementary fashion, and one in which threshold effects may exist. Even if one does not try to build a clear-cut model of this sort - and we do not pretend to do so here - it is surely useful to have the different categories of institutional development measured separately, whenever possible.

\section{Examples of studies using a variety of institutional measures}

We are not aware of any study of growth that includes all categories of institutional measure to estimate statistically their joint and separate effects. However, quite a few (generally) more recent efforts go well beyond the Barro and Sala-I-Martin use of political instability or corruption indices as in Mauro, Tanzi, and others.

Among the earlier ones are Knack and Keefer (1995), who use several different measures of effective governance from the privately compiled (and sold for profit since 1982) International Country Risk Guide (ICRG). Similarly, Olson et al. (1997) explain growth in 68 countries over the period 1960-87 by conventional neoclassical and new growth theory variables, and then explain the productivity growth residuals from this using several measures of effective governance: the risk of expropriation, risk of contract repudiation, quality of bureaucracy, level of government corruption, and rule of law. The overall results are reasonably strong and significant, with and $R^{2}$ for the latter equation of about 0.50 . A study by Poirson (1998) uses the same approach that we will present in the Institutional indicators in growth regressions section, which is to add to the conventional variables several measures of 'economic security. ${ }^{5}$ These are taken from the ICRG and are similar to those used by Olson et al., but also include the degree of civil liberty from Freedom

\footnotetext{
${ }^{5}$ An interesting theoretical model of the security factor is presented in the work of McGuire (1998), which shows that more resources for security forces are good for growth, but there is a tradeoff because rent-seeking incentives lead staff of these forces towards corruption which, of course, is not good for growth.
} 
8

House publications. These institutional variables again generally show the right signs and high statistical significance, although the explanatory powers for growth equations in panel data are surprisingly low (about 0.30) compared to those for investments (about 0.78). Pfefferman and Kisunko (1999) use recent World Bank survey data of what managers see as obstacles to doing business in different countries. Their results do not isolate the obstacles according to our three categories, and have much lower $R^{2}$ values, but clearly demonstrate that the level of private investment is greater where the predictability of the judiciary is highest and regulations for starting new operations are simple. Kaufman et al. (1999a) construct a number of governance indicators and find evidence of a strong relationship from better governance to better development outcomes, including per capita GDP.

For transition countries, de Melo et al. (1997) also analysed how the degree of political freedom is correlated with their liberalisation index, showing a very high correlation, and arguing that greater political freedom in some degree 'explains' differences in the amount of economic liberalisation, which in turn is a powerful explanatory factor in growth equations. This approach - which we argue in the final section deserves further experimentation - is also found in Wolf (1997). Although he did not rely on any of the available institutional measures, he did posit the issue in a similar way: (i) What are the underlying factors (or initial conditions such as distance to market economies, years of communism, Lutheran/Catholic/Orthodox influence) that explain the amount of 'correct' policy effort in transition countries? (ii) What is the effect of the resulting good policies on growth?

If one takes the definition of economic liberalisation as one component of institutional development, then, of course, it has to be noted that most of the transition growth analyses described in the Introduction also include this institutional variable, and find it has a very strong impact on growth. In the Institutional indicators in growth regressions section, we explore this, estimating the 'statistical value-added' of economic liberalisation on variables in growth equations and the additional and separate effect of the legal and political factors.

\section{INDICES OF INSTITUTIONAL DEVELOPMENT}

Many different agencies, both public and private, produce rankings or ratings of countries on some metric of institutional development. Some are general indicators of business risk (eg the International Country Risk Guide, ICRG), or country competitiveness (eg The World Competitiveness report), or degree of corruption (eg Transparency International). Others provide further detail of 
institutional development by categories approaching those noted in the previous section, such as political freedom or democracy, economic freedom or openness, legal framework effectiveness or property rights protection. The most comprehensive and easily accessible indicators are compiled annually by the Heritage Foundation (USA) for 148 countries since 1995, by Freedom House (USA) in their annual Survey of Freedom published for 191 countries starting in 1978, and also for transition countries in their Nations in Transit publication covering 25 countries since 1995, and for transition countries by the EBRD in its Transition Report for 25 countries since 1994. A detailed set of institutional conditions was compiled in Brunetti et al. (1997) for The World Development Report (1997). ${ }^{6}$ In this section, we focus on 9 indicators from five sources, which provide a wide coverage of transition countries: Heritage Foundation, Freedom House, EBRD, World Bank, and Euromoney (see summary in Appendix A).

The 'Index of Economic Freedom' is published by the Heritage Foundation and the Wall Street Journal, starting with data for 1994, although coverage for the full set of transition countries is only done as of 1997. There is an overall index that is based on the evaluation by outside experts of 10 specific institutional factors or areas that are considered to be relevant for economic freedom. These are: trade, taxation, government intervention, monetary policy, foreign investment, banking, wages and prices, property rights, regulation, and black market (see Holmes et al. (1995-1998) for further details on the assessment). It is very thorough and looks reasonable, but is still fundamentally subjective. In this paper, we used the overall index (HERgen) as well as the average of the subindices for property rights, which captures the protection of private property and the enforcement of contract by the legal system, and government regulation, which reflects the clarity and consistency with which regulations are applied, the overall burden imposed by regulation, and the presence of corruption (HERleg).

The 'Nations in Transit' reports from Freedom House provide a second source of institutional indicators, in addition to Freedom House's annual Survey of Freedom. Both are again based on expert outside opinion. We used the measures on democratic (FRdem) and economic freedom (FRec) of the former, which are based on subindicators for political process, civil society, independent media, rule of law, government and public administration, privatisation, and the economy. We also used the average of the subindices for rule of law and governance and public administration (FRleg). Of the annual data, we used the average of the indices for political and civil

\footnotetext{
${ }^{6}$ Kimberly (1997, Appendix B) provides a brief overview of some, but not all, of these data sets.
} 
rights (FRpol) Survey of Freedom, of which the contents are almost, but not entirely, identical to the democratic freedom indicator.

A third source that we used is the EBRD's transition indicators. These are also based on an evaluation by outside experts. In particular, we used the EBRD's legal reform index, measuring the de jure extensiveness and the de facto effectiveness of the legal systems of countries (EBRDleg). This indicator has been compiled since 1995 .

A fourth source of data was the survey conducted in 1998 by the World Bank on the institutional environment in a large number of countries for its World Development Report. The survey was divided into five sections: (i) government predictability regarding laws and policies; (ii) property rights; (iii) the quality of the government-business relationship; (iv) bureaucratic red tape; and (v) efficiency of the government in providing services. The survey reflects the situation in 1997 as perceived by a sample of firms located in these countries. We used the average of the responses to those questions that best captured institutional factors (WB).

Finally, we used the country risk ratings published by 'Euromoney', which go back to 1992 and which are based on the assessments of country-risk experts. We only used the political risk element of this rating (EUR). Although slightly different in nature, we found that the ranking of countries stemming from this indicator is fairly similar to the ones based on the other indicators.

As these measures are typically based on the judgment of outside experts, they have the clear drawback of being subjective, and contain a serious risk of reverse causation, that is, performance perceptions bias the ratings given by experts. Countries with good economic performance may be more likely to receive favourable ratings; hence, the indicator is as much an 'effect' of performance as a 'cause'. However, the picture that emerges from correlation analysis of these measures of the institutional and political environment shown in Table 1, is one of surprisingly consistent rankings, which one might not expect even with the bias noted. Kaufman et al. (1999a) also find a high degree of correlation for a much larger set of governance indicators. Thus, there is a broad agreement among observers on the ranking of countries' level of institutional development. Mauro (1997) also argued that one would not expect such subjectively compiled measures to give consistent results; therefore, the fact that they do (for corruption in his case) gives some comfort as to their reliability.

However, the rankings may be too similar. As shown in Table 1, the correlation of each of the institutional indicators with an indicator for structural reforms (EBRDri) is also very high. While, broadly speaking, economic liberties and reforms are likely to be correlated with the degree of political and civil liberties, one should surely expect many instances where 
Table 1: Correlation matrices of institutional and political indicators

\begin{tabular}{|c|c|c|c|c|c|c|c|c|c|c|c|}
\hline & Average & HERgen & HERleg & FRleg & FRec & FRdem & EUR & EBRDleg & FRpol & EBRDri & World Bank \\
\hline Average & 1 & & & & & & & & & & \\
\hline HERgen & 0.93 & 1 & & & & & & & & & \\
\hline HERleg & 0.89 & 0.91 & 1 & & & & & & & & \\
\hline FRleg & 0.99 & 0.90 & 0.87 & 1 & & & & & & & \\
\hline FRec & 0.97 & 0.88 & 0.86 & 0.97 & 1 & & & & & & \\
\hline FRdem & 0.98 & 0.90 & 0.87 & 0.99 & 0.96 & 1 & & & & & \\
\hline EUR & 0.87 & 0.77 & 0.78 & 0.83 & 0.79 & 0.82 & 1 & & & & \\
\hline EBRDleg & 0.88 & 0.82 & 0.70 & 0.83 & 0.82 & 0.80 & 0.79 & 1 & & & \\
\hline FRpol & 0.94 & 0.88 & 0.78 & 0.95 & 0.92 & 0.97 & 0.73 & 0.78 & 1 & & \\
\hline EBRDri & 0.92 & 0.81 & 0.72 & 0.88 & 0.93 & 0.87 & 0.77 & 0.85 & 0.86 & 1 & \\
\hline Average & 1 & & & & & & & & & & \\
\hline HERgen & 0.93 & 1 & & & & & & & & & \\
\hline HERleg & 0.94 & 0.96 & 1 & & & & & & & & \\
\hline FRleg & 0.98 & 0.89 & 0.89 & 1 & & & & & & & \\
\hline FRec & 0.97 & 0.88 & 0.88 & 0.96 & 1 & & & & & & \\
\hline FRdem & 0.98 & 0.89 & 0.89 & 0.99 & 0.95 & 1 & & & & & \\
\hline EUR & 0.88 & 0.78 & 0.82 & 0.83 & 0.79 & 0.83 & 1 & & & & \\
\hline EBRDleg & 0.91 & 0.86 & 0.86 & 0.87 & 0.83 & 0.84 & 0.83 & 1 & & & \\
\hline FRpol & 0.94 & 0.87 & 0.85 & 0.96 & 0.93 & 0.98 & 0.72 & 0.78 & 1 & & \\
\hline EBRDri & 0.91 & 0.79 & 0.79 & 0.87 & 0.92 & 0.86 & 0.80 & 0.80 & 0.84 & 1 & \\
\hline World Bank & 0.63 & 0.63 & 0.62 & 0.57 & 0.67 & 0.56 & 0.46 & 0.57 & 0.52 & 0.61 & 1 \\
\hline
\end{tabular}

Top half: All 25 transition countries excluding FYR Macedonia. Bottom half: All 25 transition countries excluding Croatia, FYR Macedonia, Romania, Slovenia, Tajikistan, and Turkmenistan.

Sources: Heritage Foundation, Freedom House, Euromoney, EBRD, Word Bank.

economic liberalisation outpaces the degree of democratisation: China may be a case in point. Conversely, a country may not be very liberal economically, yet possess abundant political or civil liberties: India may be an example. Furthermore, country-specific ratings derived from these approaches should be tested against 'informed' opinion to see whether they 'make sense' - whether a duck is a duck in the old American congressional test. ${ }^{7}$ There are some, but not many, anomalies; all the economic indices generally tend to rank Russia and Croatia at about the same level, which may be too high for the former and/or too low for the latter. Further, it is interesting to note that the overall EBRD rating of Russia fell from an average of 0.72 (our scaling) in 1997 to 0.61 in 1998, after the August crisis. On balance, however, we would agree with Mauro (1997) and Kaufman et al. (1999a) that the surprisingly high consistency outweighs the few anomalies, and gives one reason to feel comfortable with these measures.

Of the nine indicators we have compiled, that of the World Bank appears to be somewhat of an outlier. For all the others, pairwise correlations are

\footnotetext{
${ }^{7}$ If it looks like a duck, walks like a duck, sounds like a duck, it must be a duck.
} 
12

generally 0.80 or higher (with only a few exceptions lower than 0.80 but no less than 0.72 ). The World Bank indicator has a correlation of only 0.63 vis-àvis the average of the 10, and pairwise correlations with the others in the range of 0.46-0.67. Also, as can be seen in Figure 1, which orders countries according to the average index using all indicators, the World Bank indicator shows a distinctly flatter curve across countries, that is, it gives generally

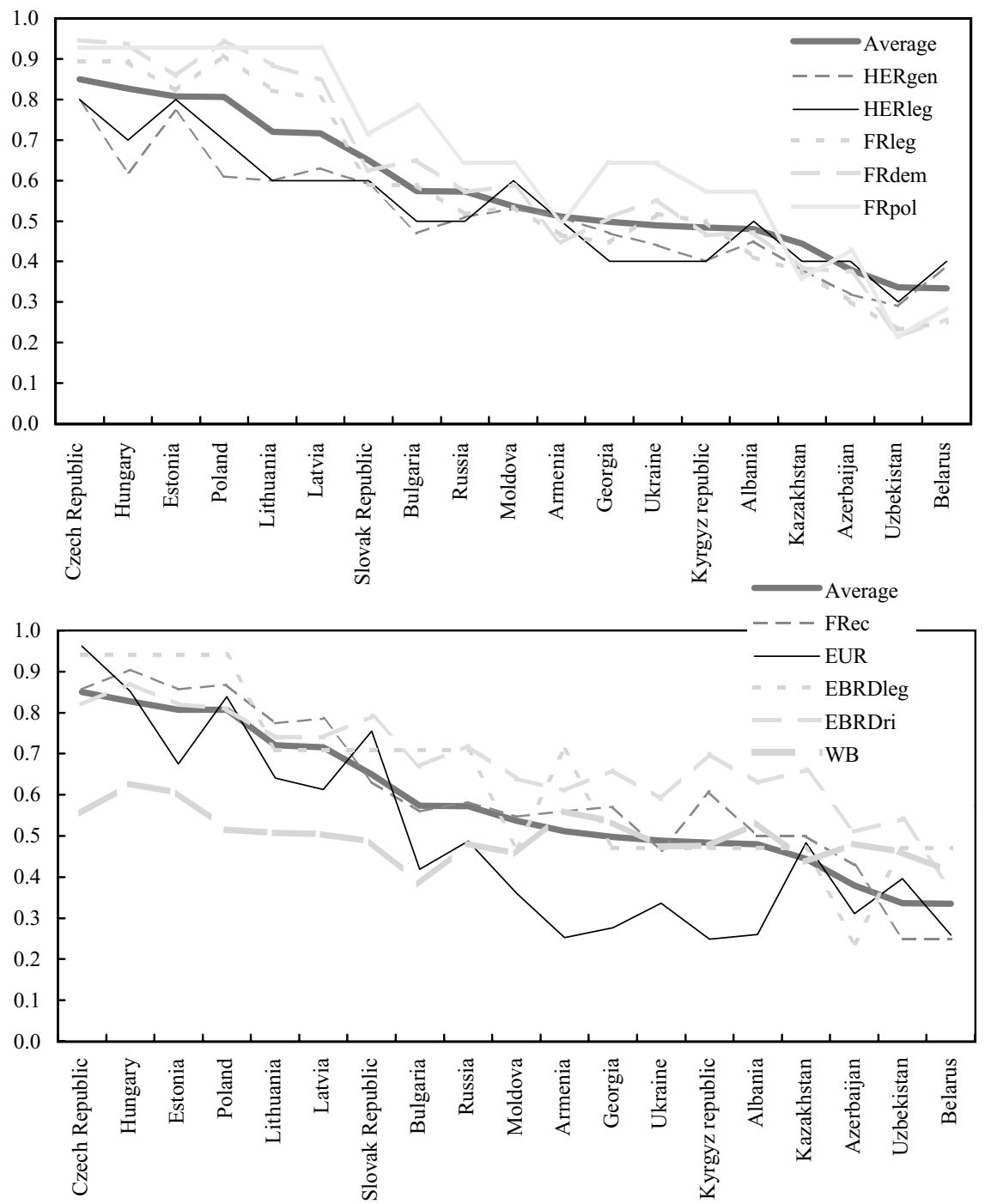

Figure 1: Institutional, political and economic reform indicators. 
lower ratings to countries shown to be more advanced by the other indicators, and slightly higher ratings to countries considered less advanced by other surveys. For this reason, and also because its country coverage is more limited (19 countries), we have not used it in any of our regression analyses in the next section.

\section{INSTITUTIONAL INDICATORS IN GROWTH REGRESSIONS}

To determine the relative importance of the institutional environment compared to the factors described in the Introduction in explaining variations among countries' performance, we have conducted a simplified econometric analysis of economic growth in transition countries. At the start, it is useful to remember that data deficiencies remain a serious problem. Hence, all conclusions should be interpreted with caution. In addition, not all data were available for all transition countries and for all years. This applies in particular to data on the institutional environment, many of which were only available for recent years.

Our starting point is the basic equation that we used in our previous study (Havrylyshyn et al. 1998). This has the growth rate of real gross domestic product (GR) as the dependent variable. As independent variables we used variables in the three categories that represent those factors believed to be important in explaining economic performance as described in the Introduction. Thus, we included the contemporaneous rate of inflation (INFL) to represent macroeconomic stabilisation policies; ${ }^{8}$ and the contemporaneous and lagged values of the structural reform index (RI) to represent economic liberalisation policies and their possible initial negative impact, ${ }^{9}$ and two 'clusters' of initial conditions capturing, respectively, macroeconomic

\footnotetext{
${ }^{8}$ Ideally, as we realise that the inflation rate is not an exogenous variable but the result of policies, the estimated relation would be derived from a structural model in which inflation is determined by other variables, such as, for example, the size of the fiscal deficit. As in most other studies trying to explain growth in transition economies, however, we include the inflation rate directly as an indicator for macrostabilisation policies.

${ }^{9} \mathrm{RI}$ is based on the EBRD transition indicators for price liberalisation, trade and exchange regime, small-scale and large-scale privatisation, governance and restructuring, and banking reform and interest liberalisation. These have been published since 1994. For earlier years, we used the indices from de Melo et al. (1996), which were based on their and other country specialists' opinion on a country's pace of reforms and its ranking relative to other transition countries. We include the contemporaneous value as well as lagged values of RI to try to capture the initial adverse effect that reforms may have on growth, although we recognise that the use of contemporaneous values has been shown to cause problems of bias in OLS estimates. More elaborate estimation techniques could be considered to avoid this, but go beyond the scope of this paper.
} 
distortions (IC1), and the level of socialist development and its associated distortions (IC2). Thus, our basic equation is:

$$
\mathrm{GR}_{i, t}=a_{0}+a_{1} \mathrm{INFL}_{i, t}+b_{1} \mathrm{RI}_{i, t}+b_{2} \mathrm{RI}_{i, t-1}+b_{3} \mathrm{RI}_{i, t-2}+c_{1} \mathrm{IC}_{i}+c_{2} \mathrm{IC}_{i}
$$

As before, data on growth and inflation are official data provided by the authorities and IMF staff estimates, while data for the reform index were taken from de Melo et al. (1996) for the years 1990-93, and updated for the years 1994-98 by linking it to the transition indicators in the EBRD's Transition reports. The two series representing initial conditions were taken from de Melo et al. (1997b), who used principal component analysis to construct these clusters based on a large data set of variables describing the macroeconomic and structural situation at the outset of transition, including pretransition levels of per capita income and growth, the degree of urbanisation, natural resource endowment, repressed inflation, the level of industrialisation, proximity to market economies, trade dependency, time under communism, black market premia, and whether a country was an independent state prior to transition. Our data panel is 1991-98 for 25 transition economies in Central and Eastern Europe and in the Baltics, Russia and other countries of the former Soviet Union. This gives a potential data set of 200 observations. However, not all series were available for all these countries and years; hence, the actual data set is from 168 to 192 observations. Equation (1) has been estimated using generalised least squares (GLS) on our panel, with $a_{0}$ set at zero and using cross-section weights to correct for heteroskedasticity. ${ }^{10}$ The results for the panel regression are shown in Table $2 .^{11}$

The results of this basic equation reproduce our earlier findings that macroeconomic policies and structural reforms are the two most important factors in explaining output developments in transition economies. Comparing equations (1) and (2) in Table 2 suggests that a combination of these two factors account for almost $90 \%$ of the variation explained by our basic equations. Moreover, structural reforms are the most important factor, as equation (3) indicates that $70 \%$ of the variation explained by equation (1) can

${ }^{10}$ Fixed or random effects estimations could not be used given the presence of the variables representing initial conditions. In earlier work, we found the coefficients of the main variables not to be significantly different if fixed effects are used instead of variables representing initial conditions. We prefer using the variables representing initial conditions instead of fixed effects because the former have more 'economic' content.

${ }^{11}$ Our earlier study included some other variables not reported on here: government expenditure was negative and significant, perhaps capturing the degree of government intervention; investment ratios were never significant and often of the wrong sign. Wolf (1997) also reaches the latter conclusion. 
Table 2: Basic regression results

\begin{tabular}{lccccccc}
\hline \multicolumn{7}{c}{ Dependent variable: GR } & \multicolumn{7}{c}{} \\
\cline { 2 - 7 } & $(1)$ & $(2)$ & $(3)$ & $(4)$ & $(5)$ & $(6)$ & $(7)$ \\
\hline INFL & -0.35 & -0.40 & -0.55 & -0.35 & -0.54 & -0.35 & -0.99 \\
& $(-5.16)$ & $(6.12)$ & $(-7.78)$ & $(-5.14)$ & $(-7.74)$ & $(5.16)$ & $(-10.59)$ \\
RI & -32.79 & -41.10 & & -32.41 & & -33.37 & \\
& $(-6.91)$ & $(-7.53)$ & & $(-6.95)$ & & $(-6.86)$ & \\
RI-1 & 25.00 & 32.04 & & 24.83 & & 25.39 & \\
& $(3.97)$ & $(4.46)$ & & $(4.01)$ & & $(3.98)$ & \\
RI-2 & 12.79 & 14.17 & & 12.11 & & 12.47 & \\
& $(4.34)$ & $(4.42)$ & & $(4.11)$ & & $(4.01)$ & 0.33 \\
IC1 & -1.83 & & -1.91 & -1.40 & -2.10 & -1.76 & $(0.57)$ \\
& $(-3.95)$ & & $(-3.14)$ & $(-2.34)$ & $(-2.53)$ & $(-3.70)$ & -2.26 \\
IC2 & -2.38 & & -1.63 & -2.82 & -1.32 & -2.37 & $(-3.06)$ \\
& $(-4.43)$ & & $(-2.02)$ & $(-4.75)$ & $(-1.24)$ & $(-4.35)$ & $(-25)$ \\
FRpol & & & & 0.12 & & \\
& & & & $(1.34)$ & $(-0.41)$ & 0.03 & 0.43 \\
EUR & & & & & & $(0.31)$ & $(7.04)$ \\
Adj. $R^{2}$ & 0.70 & 0.62 & 0.21 & 0.73 & 0.21 & 0.69 & 0.38 \\
$N$ & 168 & 168 & 192 & 168 & 192 & 168 & 192 \\
\hline
\end{tabular}

$t$-values in parentheses.

be attributed to this factor. The sum of the structural reform coefficients is clearly positive, indicating that after an initial output decline reforms significantly contribute to growth. Initial conditions do matter, but their impact appears to be less important and their negative effect can be relatively easily overcome by stepping up progress in structural reforms.

Next, we added variables that represent the level of development of market institutions to our basic equation or substituted them for the structural reform index, RI. In principle, we believe it is more correct to add these variables instead of substituting them for RI, as already noted in the Institutional conditions as determinants of growth section where we suggested that the development of market-enhancing institutions is of a different nature than the reforms captured by RI. Further, since RI was found to be an important factor in explaining economic performance in transition economies, excluding this variable would increase the risk of misspecification. Finally, as a more practical matter, replacing RI by an average of economic and institutional indices posed a problem in the context of our panel regressions, as most of the other indices were only available for the most recent years.

We recognise that there is a counterargument against using RI separately from the legal and political indicators. To some extent, the EBRD transition indicators can be considered as a result of good institutional development 
rather than a core measure of institutions themselves. Thus, one might specify the growth equation by excluding RI and including other institutional indicators. In fact when this is done, Table 2 (equations (5) and (7)), it is clear that variables such as FRpol and EUR, which are available for a longer period, do not have by themselves anything like the explanatory power of RI; only EUR is statistically significant, although in both cases the explanatory power falls dramatically to 0.21 and 0.38 , respectively, from values in the range of $0.60-0.70$ using RI. This confirms our belief that RI is an essential part of the growth explanation. A better way of dealing with the issue of what is a policy result $v s$ what is an institutional factor would be to follow the approach tentatively experimented with by Wolf (1997) as described in the Institutional conditions as determinants of growth section, that is, to explain RI using inter alia the institutional factors and then explain growth with RI but excluding institutional factors (probably using 2SLS). However, that too would miss something as noted in the Institutional conditions as determinants of growth section: the resulting 'policies' we think of as economic liberalisation are not only determined by legal and political institutions, but the impact of good policies on growth is likely to be greater, the stronger and more developed these institutions are. This view of the process argues for the frugal and simpler GLS specification we use which adds to RI other institutional variables.

Given the limited data availability of variables that represent marketenhancing institutions and taking into account that these indices are highly correlated among each other and show little change over time when they are available for more than 1 year (reflecting probably also their obviously 'rough' nature), we have tried a different approach, similar to the method that was used by de Melo et al. (1997b) when they tried to account for the effect of initial conditions. In order to reduce the subjectivity of the individual indices, as well as deal with the multicollinearity, we have used principal components analysis to best capture the 'broad consensus' of the observers who constructed the institutional indices. We first applied the principal component analysis to eight of the 10 indices described in the previous section for the year 1997, which is the only year for which all of them were available (we excluded the results from the World Bank survey because these showed only very little variation among transition countries, while the structural reform index is entered directly in the specification as explained above). Next, we used principal components analysis to determine the 'broad consensus' regarding only the indices that represent either the legal framework or the level of political freedom.

Principal component analysis indeed appears to be capturing the 'broad consensus' contained in the set of individual indices. Table 3 shows the variability in the set of individual indices explained by each principal 
Oleh Havrylyshyn \& Ron van Rooden Institutions Matter in Transition, But So Do Policies

Table 3: Results from the principal component analsysis

\begin{tabular}{|c|c|c|c|c|}
\hline Component & Variation Proportion & Cumulative & Correlations Variable & PR1 \\
\hline \multicolumn{5}{|c|}{ I. All indices (excluding EBRDri and WB) } \\
\hline PR1 & 0.873 & 0.873 & HERgen & 0.95 \\
\hline PR2 & 0.045 & 0.918 & HERleg & 0.91 \\
\hline PR3 & 0.036 & 0.954 & FRleg & 0.99 \\
\hline PR4 & 0.026 & 0.980 & $\mathrm{FRec}$ & 0.96 \\
\hline PR5 & 0.012 & 0.993 & FRdem & 0.98 \\
\hline PR6 & 0.005 & 0.997 & FRpol & 0.94 \\
\hline PR7 & 0.002 & 0.999 & EBRDleg & 0.87 \\
\hline PR8 & 0.001 & 1.000 & EUR & 0.87 \\
\hline \multicolumn{5}{|c|}{ II. Legal framework indices } \\
\hline PR1 & 0.869 & 0.869 & HERleg & 0.92 \\
\hline PR2 & 0.100 & 0.968 & FRleg & 0.97 \\
\hline PR3 & 0.032 & 1.000 & EBRDleg & 0.90 \\
\hline \multicolumn{5}{|c|}{ III. Political framework indices } \\
\hline PR1 & 0.983 & 0.983 & FRdem & 0.99 \\
\hline PR2 & 0.017 & 1.000 & FRpol & 0.99 \\
\hline
\end{tabular}

Sources: Heritage Foundation, Freedom House, Euromoney, EBRD

component, as well as the correlation of the first component with each of the individual indices. In each case, the first principal component explains close to $90 \%$ of the variability among the individual indices and has high positive correlations with each of them. Hence, we only use the first principal components in our regression analysis.

Table 4 shows a set of regressions, again using GLS with $a_{0}$ set at zero and using cross-section weights, where the first principal component of the dataset comprising all eight institutional indices (PRall) has been added to our basic equation, as well as the first principal components of the data sets comprising only indices representing the legal framework (PRleg) or political liberties (PRpol) (equations (1)-(3)). The basic finding is that including an institutional variable adds somewhat to the explanatory power of our original equation; about $5 \%$ of the total variation explained can be attributed to institutional factors. While PRall is of the correct sign but not statistically significant, PRleg is almost significant at the 5\% level, suggesting the particular importance of establishing a legal framework for restoring economic growth. The relationship between economic performance and the level of development of the institutional framework can also be seen in Figure 2, which plots the first principal component of the legal indices against the level of output in 1998 compared to that in 1990. A polynomial trendline was added, indicating a positive correlation. Figure 2 also shows that the institutional framework is generally better developed in the Central and 


\begin{tabular}{|c|c|c|c|c|c|c|c|c|c|c|}
\hline & \multicolumn{10}{|c|}{ Dependent variable: GR } \\
\hline & (1) & (2) & (3) & (4) & (5) & (6) & (7) & (8) & (9) & (10) \\
\hline INFL & $\begin{array}{c}-0.34 \\
(-5.02)\end{array}$ & $\begin{array}{l}-0.34 \\
(-5.03)\end{array}$ & $\begin{array}{l}-0.34 \\
(-5.03)\end{array}$ & $\begin{array}{l}-0.34 \\
(-5.28)\end{array}$ & $\begin{array}{l}-0.33 \\
(-4.98)\end{array}$ & $\begin{array}{l}-0.32 \\
(-4.89)\end{array}$ & $\begin{array}{l}-0.32 \\
(-4.91)\end{array}$ & $\begin{array}{l}-0.32 \\
(-4.85)\end{array}$ & $\begin{array}{l}-0.32 \\
(-5.01)\end{array}$ & $\begin{array}{c}-0.58 \\
(-7.73)\end{array}$ \\
\hline RI & $\begin{array}{l}-32.62 \\
(-7.08)\end{array}$ & $\begin{array}{l}-32.92 \\
(-7.18)\end{array}$ & $\begin{array}{l}-32.49 \\
(-6.92)\end{array}$ & $\begin{array}{l}-33.62 \\
(-7.41)\end{array}$ & $\begin{array}{l}-36.37 \\
(-7.72)\end{array}$ & $\begin{array}{l}-34.16 \\
(-7.94)\end{array}$ & $\begin{array}{l}-33.98 \\
(-7.93)\end{array}$ & $\begin{array}{l}-34.65 \\
(-7.90)\end{array}$ & $\begin{array}{l}-33.51 \\
(-7.99)\end{array}$ & \\
\hline RI-1 & $\begin{array}{l}24.82 \\
(4.04)\end{array}$ & $\begin{array}{c}25.02 \\
(4.08)\end{array}$ & $\begin{array}{c}24.92 \\
(4.00)\end{array}$ & $\begin{array}{l}23.76 \\
(3.84)\end{array}$ & $\begin{array}{c}29.21 \\
(4.53)\end{array}$ & $\begin{array}{l}27.61 \\
(4.60)\end{array}$ & $\begin{array}{l}27.43 \\
(4.58)\end{array}$ & $\begin{array}{c}28.14 \\
(4.62)\end{array}$ & $\begin{array}{c}26.13 \\
(4.43)\end{array}$ & \\
\hline RI-2 & $\begin{array}{l}12.32 \\
(4.17)\end{array}$ & $\begin{array}{l}12.31 \\
(4.14)\end{array}$ & $\begin{array}{l}12.35 \\
(4.20)\end{array}$ & $\begin{array}{l}14.26 \\
(4.60)\end{array}$ & $\begin{array}{l}12.77 \\
(4.15)\end{array}$ & $\begin{array}{l}10.96 \\
(3.42)\end{array}$ & $\begin{array}{l}10.87 \\
(3.40)\end{array}$ & $\begin{array}{l}11.21 \\
(3.50)\end{array}$ & $\begin{array}{l}11.53 \\
(3.63)\end{array}$ & \\
\hline IC1 & $\begin{array}{l}-1.30 \\
(-2.06)\end{array}$ & $\begin{array}{c}-1.13 \\
(-1.83)\end{array}$ & $\begin{array}{c}-1.59 \\
(-2.61)\end{array}$ & $\begin{array}{l}-1.10 \\
(-1.85)\end{array}$ & & & & & & \\
\hline IC2 & $\begin{array}{c}-2.77 \\
(-4.92)\end{array}$ & $\begin{array}{c}-2.67 \\
(-4.92)\end{array}$ & $\begin{array}{c}-2.62 \\
(-4.67)\end{array}$ & $\begin{array}{c}-1.92 \\
(-3.42)\end{array}$ & & & & & & \\
\hline IC1T & & & & & $\begin{array}{c}-7.72 \\
(3.85)\end{array}$ & $\begin{array}{c}-7.37 \\
(-3.95)\end{array}$ & $\begin{array}{c}-7.17 \\
(-3.87)\end{array}$ & $\begin{array}{c}-7.52 \\
(-3.97)\end{array}$ & $\begin{array}{c}-6.93 \\
(-3.80)\end{array}$ & $\begin{array}{c}-0.52 \\
(-0.25)\end{array}$ \\
\hline IC2T & & & & & $\begin{array}{l}-13.81 \\
(-5.39)\end{array}$ & $\begin{array}{l}-16.14 \\
(-6.42)\end{array}$ & $\begin{array}{l}-15.55 \\
(-6.27)\end{array}$ & $\begin{array}{l}-16.14 \\
(-6.34)\end{array}$ & $\begin{array}{l}-13.44 \\
(-5.33)\end{array}$ & $\begin{array}{l}-15.96 \\
(-5.38)\end{array}$ \\
\hline PRall & $\begin{array}{c}0.94 \\
(1.53)\end{array}$ & & & & & & & & & \\
\hline PRleg & & $\begin{array}{c}1.09 \\
(1.90)\end{array}$ & & $\begin{array}{c}3.78 \\
(2.93)\end{array}$ & & & & & & \\
\hline PRpol & & & $\begin{array}{c}0.49 \\
(0.86)\end{array}$ & $\begin{array}{c}-3.12 \\
(-2.40)\end{array}$ & & & & & & \\
\hline PRallT & & & & & & $\begin{array}{c}0.17 \\
(2.97)\end{array}$ & & & & $\begin{array}{c}0.53 \\
(6.73)\end{array}$ \\
\hline PRlegT & & & & & & & $\begin{array}{c}0.18 \\
(3.13)\end{array}$ & & $\begin{array}{c}0.52 \\
(2.83)\end{array}$ & \\
\hline PRpolT & & & & & & & & $\begin{array}{c}0.14 \\
(2.49)\end{array}$ & $\begin{array}{c}-0.38 \\
(-1.98)\end{array}$ & \\
\hline Adj. $R^{2}$ & 0.73 & 0.73 & 0.72 & 0.74 & 0.70 & 0.76 & 0.76 & 0.75 & 0.77 & 0.35 \\
\hline$N$ & 168 & 168 & 168 & 168 & 168 & 168 & 168 & 168 & 168 & 192 \\
\hline
\end{tabular}

$t$-values in parentheses. 
Oleh Havrylyshyn \& Ron van Rooden Institutions Matter in Transition, But So Do Policies

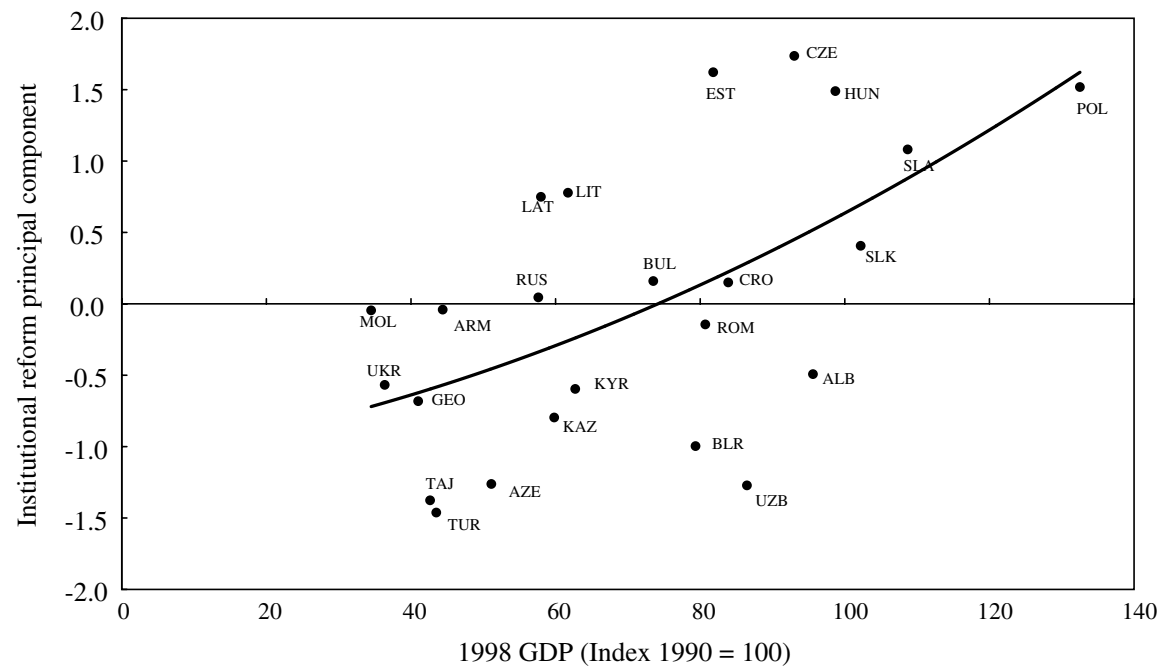

Figure 2: Growth and institutional reforms.

Eastern European countries and in the Baltics. These countries had more of an institutional framework already in place before the start of the transition process, and have spent less time under communism than the CIS countries.

Political liberties appear to be of less importance. When combined with the legal variable (equation (4)), PRpol becomes significant but with a negative coefficient, which, taken literally, would suggest that political liberties actually hurt growth prospects. While this implausible result is probably caused mainly by the multicollinearity between the two variables, one should not forget that in the short run, there have been examples where progress in implementing reforms has been slowed down or stopped by relatively freely elected parliaments opposing more reformist governments. Part of the story of lagging reforms in Russia and Ukraine may be of this type; Polish parliaments have at a minimum slowed reform of pensions; Latvian parliaments have been more protectionist on agriculture than the governments.

The next question we tried to answer is whether the effects of both initial conditions and of market-enhancing institutions can be assumed to have the same intensity over time. In our panel data context, the same value of the initial condition and institutional variables is entered into the data set for each year of the sample. This might be too strong an assumption. Intuitively, one would expect the effect of adverse initial conditions to diminish over time, as the economy is increasingly transformed into a market economy. In the same vein, one might expect that after the initial stabilisation and liberalisation, the establishment and effective implementation of strong legal 
institutions becomes increasingly important for achieving sustainable growth. As mentioned before, by their very nature, the establishment of these institutions takes more time than, for example, price liberalisation, but there is a growing understanding that developing institutions that create a marketfriendly environment cannot be delayed for too long without running the risk of reversing macroeconomic stability and stalling the overall reform process.

To test for these assumptions, we made the variables representing initial conditions and the institutional framework time dependent, with the prior assumption that the impact of adverse initial conditions declines over time (IC $T_{i, t}=\mathrm{IC}_{i} / T$ ), while the effect of the institutional environment is assumed to increase over time (PRleg $T_{i, t}=\operatorname{PRleg}_{i * T}$ ). Admittedly, modelling time dependence in this way is quite arbitrary, but given the lack of data it seems a reasonable second-best approach that could provide helpful insights. The results are shown in Table 4, equations (5)-(9). While making the initial conditions time dependent (equation (5)) increases their statistical significance, this by itself does not result in an improvement in the overall goodness of fit compared to our basic equation (1) in Table 2 . However, when a time-dependent variable for the institutional conditions is added, the overall goodness of fit of the estimates and the statistical significance of this variable increase significantly. Almost 10 percent of the variation explained by equations (6) and (7) can be attributed to the institutional factors. This means that the relevance of institutional factors is in the same order of magnitude as that of initial conditions. Moreover, while the importance of adverse initial conditions is declining with time, our results confirm the growing importance of establishing a sound institutional environment for a country's economic performance.

\section{CONCLUSIONS}

\section{Consensus of earlier studies on growth in transition}

Empirical studies of recovery and growth in transition economies have emphasised three categories of determinants: macroeconomic stabilisation; progress in economic liberalisation; and initial conditions. Generally, they have not included institutional development as separate, measurable variables except in limited bivariate correlations showing that greater economic liberalisation tends to coincide with greater political freedom.

It is almost universally agreed that stabilisation of inflation levels is a necessary - but not sufficient - condition for recovery and growth to begin.

There is also a wide consensus on the eventual positive impact on growth of liberalisation of policies and related structural reforms. Differences remain on several detailed aspects of this however: Is liberalisation necessarily 
painful early on, and how long and strong is this pain before the gains register? Can growth preceding significant reform be sustained? Is botched privatisation better than no privatisation?

On initial conditions, there remains the greatest degree of dispute. Although virtually all analysts agree that initial conditions do matter, some believe they matter a great deal; others find the impact is there but small. Another view is that the effect diminishes over time, and matters more in explaining output decline than in explaining growth once the stabilisation and liberalisation policies are put in place. A broader view is that the initial conditions do not affect growth directly, but determine the degree and speed of reform policies undertaken by the government.

It is notable that conventional factor input or technology determinants of growth (investment, human capital) are not statistically significant for transition countries. This should not be so surprising; the recovery from the transition depression is likely to be based on vast reallocation and efficiency improvements, that is, on 'creative destruction'.

\section{The value-added of institutional variables}

The spate of empirical analyses spawned by the new growth theory include many that incorporate some measure of institutional development, usually in a large sample of countries for periods about 1960 to about 1990, and therefore excluding transition countries. At the same time, the number of different cardinal measures of institutional development has proliferated, including for transition countries. Our paper builds on the above two foundation blocks to compile a set of such institutional indicators for transition countries and apply simple GLS analysis of growth, including such indicators.

The nine indicators we have compiled show a surprisingly high consistency of the country ratings by different measures. Alas, they also appear consistent in making the same errors, that is, rating countries much higher or lower than suggested by common sense. Nevertheless, on balance the great similarity of these indicators gives some comfort that the subjectivity and reverse causation biases (perception of performance influences ratings) are not so serious as to render the indicators useless.

When one asks how much statistical value is added to econometric explanations of growth by indicators of institutional development, the short answer is a significant but perhaps not overwhelming amount. Certainly, the effects are signed as expected, are strongly significant in $t$-tests, and are visible both for overall average indicators of all categories of institutional development as well as for separate components such as economic, legal, and political framework. 
However, good economic policies (including economic liberalisation) remain the dominant statistical determinant of growth in the transition economies. This conclusion is particularly clear if such indicators as economic freedom or economic liberalisation are narrowly interpreted as measures of government policies rather than institutional development, as we have done in this paper.

Once stabilisation and economic liberalisation policies are accounted for, the separate and additional effect of legal and political variables is much smaller, although clearly still significant in the econometric results.

We began with a statement of Hernando de Soto that is both pithy and, we believe, correct. Let us end with a statement of his that is equally pithy but, we believe, less correct: 'I predict...that the countries... [making the jump to a developed market economy]... will be those that spend their energies ensuring that property rights are widespread and protected by law; rather than those that continue to focus on macroeconomic policy' (our italics). We interpret the results of our paper as saying that, yes, it is good that the owners' dogs bark and perhaps thereby press governments to enforce legal support for a market economy, which in turn promotes growth and prosperity. But you still need to get the prices rights and keep them stable.

\section{REFERENCES}

Banerjee, AV. 1997: A theory of misgovernance. The Quarterly Journal of Economics. CXII(4): 1289-1332.

Barro, RJ and Sala-I-Martin, X. 1994: Economic Growth. Mc-Graw Hill: New York.

Berg, A, Borensztein E, Sahay R and Zettelmeyer, J. 1999: The evolution of output in transition economies: explaining the difference. IMF Working Paper No. WP/99/73, Washington.

Brunetti, A, Kisunko G and Weder, B. 1997: 'Institutional obstacles to doing business'. World Bank Policy Research Working Paper, No. 1759, Washington.

Calamitsis, E, Basu, A and Ghura, D. 1999: 'Adjustment and growth in Sub-Saharan Africa'. IMF Working Paper, WP/99/51, Washington.

De Melo, M, Denizer, C and Gelb, A. 1997a: From plan to market: patterns of transition. (Chapter 1). In: Blejer, M. and Skreb, M. (eds). Macroeconomic stabilization in transition economies. Cambridge University Press: Cambridge, pp. 17-72.

De Melo, M, Denizer, C, Gelb A and Tenev, S. 1997b: 'Circumstance and choice: the role of initial conditions and policies in transition economies'. Forthcoming World Bank Policy Research Working Paper, No. 1866, The World Bank: Washington.

De Soto, H. 1998: The missing ingredient. The Economist.

Easterly, W and Levine, R. 1998: Africa's growth tragedy: policies and ethnic divisions. The Quarterly Journal of Economics 451(4): 203-1250.

Euromoney, September Issues. 1992-1998.

Elliot, K.A. (ed). 1997: Corruption and the Global Economy. Institute of International Economics: Washington.

European Bank of Reconstruction and Development. various years: Transition Report. EBRD: London.

Fischer, S, Sahay, R and Vegh, C. 1996: Economies in transition: the early experience. Journal of Economic Perspectives 10(2): 45-66. 
Havrylyshyn, O. 2001. 'Recovery and growth in transition: a decade of evidence'. IMF Staff Papers, Vol. 48, Special Issue, pp. 53-87.

Havrylyshyn, O, Izvorski, I and van Rooden, R. 1998: 'Recovery and growth in transition economies 1990-97 - a stylized regression analysis'. IMF Working Paper No. 98/141, Washington.

Havrylyshyn, O, Wolf, T, Berengaut, J, Castello-Branco, M, van Rooden, R and Mercer-Blackman, V. 1999: 'Growth experience in transition countries, 1990-1998'. IMF Occasional Paper No. 184, Washington.

Holmes, KR, Johnson, BT and Kirkpatrick, M. 1995-1998: Index of Economic Freedom. The Heritage Foundation and The Wall Street Journal: Washington.

Karatnycky, A, Motyl, A and Shor, B. (eds). 1997: Nations in Transit.

Kaufman, D, Kraay, A and Zoido-Lobatón, P. 1999a: Governance Matters (mimeo).

Kaufman, D, Kraay A and Zoido-Lobatón, P. 1999b: Aggregating Governance Indicators (mimeo).

Knack, S and Keefer, P. 1995: Institutions and economic performance: cross-country tests using alternative institutional measures. Economics and Politics. 7: 207-227.

Mauro, P. 1997: The effects of corruption on growth, investment and government expenditure: a cross-country analysis (Chapter 47). In: Elliot KA (ed). Corruption and the Global Economy. Institute of International Economics: Washington.

McGuire, M. 1998: The security factor in the political economy of development. IMF Working Paper, WP/98/33, Washington.

Murrell, P. 1996: How far has transition progressed? Journal of Economic Perspectives 10(2): 25-94.

Murrell, P. 1992: Evolution in economies and in the economic reform of the centrally planned economies. In: Clague, C and Rausser, G. (eds). The Emergence of Market Economies in Eastern Europe. L Blackwell: Cambridge, MA. pp. 35-53.

North, DC. 1990: Institutions, Institutional Change and Economic Performance. Cambridge University Press: Cambridge, England.

North, DC. 1993: Institutions and credible commitment. Journal of Institutional and Theoretical Economies 149(1): 11-23.

Olson, M, Sarra, M and Swamy, AJ. 1997: Governance and Growth. University of Maryland, IRIS Center.

Posner, RA. 1998: Creating a legal framework for economic development. The World Bank Research Observer 13(1): 1-12.

Pfefferman, GJ and Kisunko, G. 1999: 'Perceived obstacles to doing business: worldwide survey results'. Draft Paper, International Finance Corporation, January 5, 1999.

Poirson, H. 1998: 'Economic security, private investment, and growth in developing countries'. IMF Working Paper, WP/98/4, Washington.

Tanzi, V and Davoodi, H. 1997: 'Corruption, public investment and growth'. IMF Working Paper, WP/97/139, Washington.

Wei, S-J. 1998: ‘Corruption in economic development'. Draft Paper, Harvard University and National Bureau of Economic Research.

Wolf, H. 1997: 'Transition strategies: choices and outcomes'. New York University, Stern Business School.

World Bank 1996: 'From plan to market', World Development Report, Washington.

World Bank 1997: 'The state in a changing world'. World Development Report, Washington.

\section{APPENDIX A}

Ten indicators from five sources provide a wide coverage of transition countries (see Table 5). 


\begin{tabular}{|c|c|c|c|c|c|c|c|c|c|c|c|}
\hline & \multicolumn{2}{|c|}{ Heritage Foundation } & \multicolumn{4}{|c|}{ Freedom House } & \multicolumn{2}{|c|}{ EBRD } & \multirow{2}{*}{$\begin{array}{c}\text { World Bank } \\
\text { Property rights } \\
\text { and public } \\
\text { administration }\end{array}$} & \multirow{2}{*}{$\begin{array}{c}\text { Euromoney } \\
\begin{array}{c}\text { Political } \\
\text { risk }\end{array}\end{array}$} & \multirow[t]{2}{*}{ Averag } \\
\hline & $\begin{array}{l}\text { Index of } \\
\text { economic } \\
\text { freedom }\end{array}$ & $\begin{array}{l}\text { Property } \\
\text { rights } \\
\text { and regulation }\end{array}$ & $\begin{array}{c}\text { Political and } \\
\text { civil rights }\end{array}$ & $\begin{array}{l}\text { Democratic } \\
\text { freedom }\end{array}$ & $\begin{array}{l}\text { Economic } \\
\text { freedom }\end{array}$ & $\begin{array}{c}\text { Rule of law } \\
\text { and public } \\
\text { administration }\end{array}$ & $\begin{array}{l}\text { Reform } \\
\text { index }\end{array}$ & $\begin{array}{l}\text { Legal } \\
\text { index }\end{array}$ & & & \\
\hline \multicolumn{12}{|c|}{ Central and Eastern Europe } \\
\hline Albania & 0.45 & 0.50 & 0.57 & 0.47 & 0.50 & 0.41 & 0.63 & 0.47 & 0.53 & 0.26 & 0.48 \\
\hline Bulgaria & 0.47 & 0.50 & 0.79 & 0.65 & 0.56 & 0.59 & 0.67 & 0.71 & 0.38 & 0.42 & 0.57 \\
\hline Czech Republic & 0.80 & 0.80 & 0.93 & 0.95 & 0.86 & 0.89 & 0.82 & 0.94 & 0.56 & 0.96 & 0.85 \\
\hline FYR Macedonoia & $\mathrm{N} / \mathrm{A}$ & $\mathrm{N} / \mathrm{A}$ & 0.64 & 0.58 & 0.48 & 0.54 & 0.67 & 0.47 & 0.57 & 0.39 & 0.54 \\
\hline Hungary & 0.62 & 0.70 & 0.93 & 0.94 & 0.90 & 0.89 & 0.87 & 0.94 & 0.63 & 0.85 & 0.83 \\
\hline Poland & 0.61 & 0.70 & 0.93 & 0.95 & 0.87 & 0.91 & 0.81 & 0.94 & 0.51 & 0.84 & 0.81 \\
\hline Romania & 0.54 & 0.40 & 0.86 & 0.60 & 0.50 & 0.55 & 0.66 & 0.71 & $\mathrm{~N} / \mathrm{A}$ & 0.58 & 0.60 \\
\hline Slovak Republic & 0.59 & 0.60 & 0.71 & 0.62 & 0.63 & 0.59 & 0.79 & 0.71 & 0.49 & 0.76 & 0.65 \\
\hline Solvenia & 0.58 & 0.70 & 0.93 & 0.88 & 0.83 & 0.86 & 0.77 & 0.71 & N/A & 0.84 & 0.79 \\
\hline \multicolumn{12}{|l|}{ Baltics } \\
\hline Estonia & 0.77 & 0.80 & 0.93 & 0.86 & 0.86 & 0.82 & 0.82 & 0.94 & 0.61 & 0.68 & 0.81 \\
\hline Lithuania & 0.60 & 0.60 & 0.93 & 0.88 & 0.77 & 0.82 & 0.74 & 0.71 & 0.51 & 0.64 & 0.72 \\
\hline \multicolumn{12}{|l|}{ CIS } \\
\hline Armenia & 0.51 & 0.50 & 0.50 & 0.45 & 0.56 & 0.46 & 0.61 & 0.71 & 0.56 & 0.25 & 0.51 \\
\hline Azerbaijan & 0.32 & 0.40 & 0.43 & 0.37 & 0.43 & 0.30 & 0.51 & 0.24 & 0.48 & 0.31 & 0.38 \\
\hline Belarus & 0.39 & 0.40 & 0.29 & 0.26 & 0.25 & 0.25 & 0.37 & 0.47 & 0.41 & 0.26 & 0.33 \\
\hline Georgia & 0.47 & 0.40 & 0.64 & 0.51 & 0.57 & 0.45 & 0.66 & 0.47 & 0.53 & 0.28 & 0.50 \\
\hline Kazakhstan & 0.38 & 0.40 & 0.36 & 0.38 & 0.50 & 0.38 & 0.66 & 0.47 & 0.44 & 0.48 & 0.44 \\
\hline Kyrgyz Republic & 0.40 & 0.40 & 0.57 & 0.46 & 0.61 & 0.50 & 0.70 & 0.47 & 0.48 & 0.25 & 0.48 \\
\hline Moldova & 0.53 & 0.60 & 0.64 & 0.59 & 0.55 & 0.54 & 0.64 & 0.47 & 0.46 & 0.36 & 0.54 \\
\hline Russia & 0.51 & 0.50 & 0.64 & 0.57 & 0.58 & 0.52 & 0.72 & 0.71 & 0.48 & 0.49 & 0.57 \\
\hline Tajikistan & 0.32 & 0.40 & 0.29 & 0.32 & 0.27 & 0.23 & 0.39 & 0.24 & $\mathrm{~N} / \mathrm{A}$ & 0.24 & 0.30 \\
\hline Turkmenistan & 0.30 & 0.40 & 0.14 & 0.15 & 0.23 & 0.18 & 0.36 & 0.24 & $\mathrm{~N} / \mathrm{A}$ & 0.35 & 0.26 \\
\hline Ukraine & 0.44 & 0.40 & 0.64 & 0.55 & 0.46 & 0.52 & 0.59 & 0.47 & 0.47 & 0.34 & 0.49 \\
\hline Uzbekistan & 0.29 & 0.30 & 0.21 & 0.21 & 0.25 & 0.23 & 0.54 & 0.47 & 0.46 & 0.40 & 0.34 \\
\hline
\end{tabular}

Sources: Heritage Foundation, Freedom House, Euromoney, EBRD, World Bank

Note: Individual indicators have been rescaled to range between 0 and 1, and in the case of the Heritage Foundation and Freedom House indicators, have been reordered to show higher values for better performance. 